\title{
Evaluasi Pembelajaran Pendidikan Agama Kristen Menggunakan Model Context, Input, Process, and Product
}

\author{
Anita Pa Padja ${ }^{1}$, Ezra Tari ${ }^{2}$, Hendrik. A.E. Lao ${ }^{3}$ \\ ${ }^{1,2,3}$ Program Studi Magister Pendidikan Agama Kristen, \\ Institut Agama Kristen Negeri Kupang \\ Email: tariezra@gmail.com
}

\begin{abstract}
Abstrak
Tujuan dari riset ini ialah mengevaluasi proses belajar dengan menggunakan pendekatan Model Context, Input, Process, Product pada mata pelajaran Pendidikan Agama Kristen. Dalam pra penelitian di SMP Negeri 12 Kupang, peneliti menemukan guru belum mengetahui kebutuhan dasar siswa. Guru belum mengetahui latar belakang siswa serta kurangnya penggunaan media pembelajaran. Tipe riset ini menggunakan pendekatan context, input, process, product. Hasil penelitian memperlihatkan bahwa pertama, pelaksanaan proses belajar dilihat dari segi konteks tergolong baik. Kedua, perencanaan program, ditemukan tidak terdapat analisis kebutuhan. Pelaksanaan program pembelajaran ditinjau dari segi input masuk dalam kategori baik. ketiga, pelaksanaan pembelajaran masih dalam kategori kurang efektif ditinjau dari segi proses. Keempat, guru melaksanakan pendahuluan dengan baik dan benar sesuai dengan rancangan yang ada di dalam RPP. Kelima, program pembelajaran perlu dirancang terstruktur sesuai dengan alokasi waktu karena menjadi faktor penentu dalam proses pembelajaran, keluasan dan kedalam materi pelajaran.
\end{abstract}

Kata kunci: Evaluasi, Pembelajaran, Model CIPP

\section{Evaluation of Christian Religious Education Learning Using the Context, Input, Process, and Product Model}

\author{
Anita Pa Padja ${ }^{1}$, Ezra Tari ${ }^{2 *}$ Hendrik. A.E. Lao ${ }^{3}$ \\ ${ }^{1,2,3}$ Christian Religious Education Master Program \\ State Institute Chrstian Religious Studies Kupang \\ Email: tariezra@gmail.com
}

\begin{abstract}
The purpose of this research is to evaluate the learning process using the Context, Input, Process, Product Model approach in Christian Religious Education subjects. In pre-research at SMP Negeri 12 Kupang, researchers found that teachers did not know the basic needs of students. The teacher does not know the student's background and the lack of use of learning media. This type of research uses a context, input, process, product approach. The results showed that first, the implementation of the learning process in terms of context was classified as useful. Second, program planning found no needs analysis. The implementation of the learning program in terms of input is in a suitable category. Third, the implementation of learning is still in the ineffective category in terms of process. Fourth, the teacher implements the introduction correctly and adequately according to the design in the RPP. Fifth, the learning program needs to be structured following the time allocation because it is a determining factor in the learning process, its breadth and into the subject matter.
\end{abstract}

Keywords: Evaluation, Learning, CIPP Model 


\section{PENDAHULUAN}

Tulisan ini berangkat dari persoalan yang ditemui oleh penulis secara empiris, bahwa evaluasi proses belajar Pendidikan Agama Kristen (PAK) di SMP Negeri 12 Kupang masih belum diterapkan dengan maksimal. Hal ini terbukti pada saat peneliti melakukan pra penelitian. Salah satu guru PAK di SMP Negeri 12 Kupang yang mengatakan bahwa Pembelajaran PAK yang dirancangkan belum dijalankan dengan baik. Guru belum maksimal mengetahui mengenai kebutuhan siswa, masalah-masalah yang dihadapi oleh siswa pada zaman milenial, peluang dalam lingkungan (sarana prasarana yang terbatas).

Aktifitas pembelajaran terlihat monoton, kurangnya penggunaan media pembelajaran karena sarana prasarana yang kurang mendukung proses pembelajaran. Rancangan pembelajaran, strategi dan metode pembelajaran dibuat hanya untuk memenuhi administrasi semata.

Evaluasi ialah riset terapan yang akan dipakai menuntaskan permasalahan yang muncul dalam kehidupan warga. Untuk menyelesaikan masalah tersebut, maka penelliti mencari pokok permasalahannya untuk diteliti dan hasilnya akan digunakan untuk menyelesaikan masalah yang ada". Menurut Henry Eryanto (Eryanto et al., 2016), evaluasi program ialah susunan kegiatan yang dikerjakan dengan terencana serta teliti guna mengenali tingkatan keterlaksanaan atau kesuksesan suatu program. Karena itu, program pembelajaran yang dirancang oleh guru demi tujuan yang akan dicapai, diketahui berhasil atau tidaknya tujuan program pembelajaran maka diperlukan evaluasi program pembelajaran. Widoyoko mendefinisikan program ialah serangkaian kegiatan yang direncanakan dengan teliti dan penerapannya berjalan berkelanjutan serta terjalin dalam sesuatu sistem yang menyertakan banyak orang (Widoyoko, 2013). Jadi evaluasi program proses belajar dilakukan terencana dan teliti untuk mengeenali tingkat terlaksananya dan kesusksesan program proses belajar dan diketahui keefektifannya.

Evaluasi program pembelajaran dikatakan baik jika dilakukan dengan baik sesuai dengan kriteria-kriteria. Penilaian meliputi: pertama, pembuatan standar buat memperhitungkan mutu serta memutuskan apakah standar tersebut bertabiat relatif ataupun mutlak. Kedua, pengumpulan data yang relevan, serta. Ketiga, pelaksanaan standar tadi buat memastikan nilai, mutu, khasiat, daya guna, ataupun signifikansi (Mahmudi, 2011). Ada beberapa bentuk penilaian yang kerap dipakai menilai pembelajaran dalam bidang pendidikan. Salah satu pola evaluasi tersebut adalah penilaian dengan pola Context, Input, Process, and Product ( CIPP) dipakai untuk 
memperhitungkan suatu program, tercantum program pembelajaran (Junanto \& Kusna, 2018).

Jadi, tulisan ini hadir memberi pencerahan, menjembatani dan memberi kontribusi terhadap masalah di tempat penelitian. Dampaknya nampak ketika mengajak para guru agama Kristen untuk memperbaiki sistem/proses pembelajaran yang selama ini dilakukan hanya sekedar rutinitas dan memenuhi jam mengajar.

Hasil Studi mengenai evaluasi pembelajaran yang dilakukan oleh Mawarsari dan Prihaswati (Mawarsari \& Prihaswati, 2014) menemukan bahwa penerapan pendidikan matematika pada kejar paket B di Semarang tercantum dalam jenis rendah sebesar 15\%. Bakti menciptakan kalau Penilaian Program CIPP. Model ini diusulkan oleh Stufflebeam pada tahun 1983. Model CIPP (Konteks, Input, Proses, and Produk) dapat digunakan untuk kedua jenis evaluasi, sumatif dan formatif (Aziz et al., 2018). Pada pembelajaran IPA sukses menggapai tujuan bersumber pada kriteria Produk pada pelajaran IPA sebesar $76 \%$ (Bhakti, 2017).

Temuan Mirwati (Mirwati et al., 2015) pelaksanaan program pembelajaran Kimia pada SMA Negeri 3 Watansoppeng dilihat dari aspek konteks ditemukan tujuannya telah serupa dengan standar prosedur, penilaian input sesuai dengan standar prosedur serta hasilnya amat positif, pada penilaian cara penerapan belajar kimia serta kemampuan guru kimia amat cakap, pada dorongan berlatih meraih kesesuaian 61,37\%. Pada penelitian di atas, peneliti menemukan perbedaan yakni pada awalnya penerapan pendidikan masih rendah namun setelah diterapkan model pembelajaran CIPP terjadi peningkatan. Penelitian kedua dan ketiga, pembelajaran sudah sesuai dengan proses sehingga hasilnya tinggi.

Berdasarkan hasil penelitan di atas, penulis fokus Pada SMP Negeri 12 Kupang. Permasalahan yang ditemui ketika melakukan pra penelitian. proses pembelajaran yang kurang mendukung, maka sangat memberi dampak bagi produk sekolah yang berhubungan dengan hasil belajar peserta didik.

Jadi perlu diadakan evaluasi terhadap program pembelajaran, demi tercapainya tujuan pembelajaran dan untuk meningkatkan kualitas pembelajaran yang dirancang oleh guru. Evaluasi pembelajaran yang akan dipakai oleh peneliti adalah evaluasi model CIPP.

\section{METODE}

Studi Penilaian dengan memakai pendekatan CIPP ( Context, Input, Process, Product) yang dikembangkan oleh Stufflebeam. Bentuk penilaian ini sesuai dengan proses penilaian proses belajar 
Pendidikan Agama Kristen di SMP Negeri 12 Kupang. Model Borg \& Gall yakni; penelitian dan pengumpulan informasi. Pengumpulan data dalam riset ini dituntut buat mulai mengumpulkan data secara rinci serta mengumpulkan beberapa kasus yang ditemui dalam riset di lapangan. Peneliti memberi inisial pada dua responden yang diwawancara yakni MK dan SB. (Muyasaroh \& Sutrisno, 2014).

Komponen konteks yang dievaluasi terdiri dari sumber daya manusia. proses yang dievaluasi yaitu koherensi pembelajaran. Produk yang dievaluasi terdiri dari kuantitas dan kualitas (Winarni et al., 2017).

\section{HASIL DAN PEMBAHASAN}

Setelah menemukan berbagai problem di latar belakang, maka dalam bagian ini penulis menjelaskan tujuan, input, proses, dan produk sebagai berikut:

\section{Tujuan}

Pada item tujuan pembuatan program pembelajaran mencakup tentang Standar Kompetensi Lulusan (SKL) dan analisis kebutuhan. Untuk mencapai tujuan pembelajaran yang baik, maka dibutuhkan pemahaman terhadap SKL dan pembuatan analisis kebutuhan yang tepat.

Standar Kompetensi Lulusan

Berdasarkan hasil penelitian dalam pembuatan program pembelajaran di SMP
Negeri 12 Kupang, guru menggunakan SKL sebagai acuan. Hal ini sejalan dengan tuntutan kurikulum dalam Permendikbud No. 20 Tahun 2016 mengenai Standar Kompetensi Lulusan Pendidikan Dasar dan Menengah.

Konteks ini membuat peneliti melihat bahwa tujuan dibuatnya program proses belajar PAK di SMP Negeri 12 Kupang memenuhi kriteria karena didasarkan pada SKL. Fokus belajar bermakna adalah mengkonstruksi pengetahuan sebagai usaha memahami pengalaman-pengalaman siswa (Darmawan \& Sujoko, 2013). Hal ini sejalan dengan hasil wawancara tentang tujuan pembuatan program pembelajaran pendidikan agama adalah untuk meraih hasil melatih diri siswa sesuai dengan SKL yang mencakup hasil belajar kognitif, afektif dan psikomotor" (Responden MK). Seperti halnya C. Rudy Prihantoro (Rudy, 2015) menerangkan Standar Kompetensi Lulusan (SKL) dalam perihal ini diharapkan bisa tingkatkan serta menyeimbangkan antara soft skill serta hard skill yakni, aspek kemampuan perilaku meliputi: kepercayaan individu, moralitas, yakin diri, serta tanggung jawab dalam berhubungan. Efisien dengan area sosial, alam dekat, dan dunia serta peradabannya, keahlian (tercantum: seorang yang mempunyai pemikiran efisien serta kreatif dalam ranah abstrak serta kongkret), serta pengetahuan (keahlian buat 
menciptakan memahami ilmu, ilmu, teknologi, seni, serta budaya yang bertumpu pada kemanusiaan, kebangsaan, bernegara, serta peradaban).

Sesuai dengan fakta, teori dan regulasi tentang peranan SKL terhadap perencanaan program pembelajaran, maka menurut peneliti kondisi ini sudah benar dan harus dipertahankan oleh setiap guru dalam merencanakan program pembelajaran.

Analisis kebutuhan

Dalam membuat program pembelajaran di SMP Negeri 12 Kupang sesuai fakta bahwa "analisis kebutuhan itu seperti apa? Saya tidak membuat analisis kebutuhan" (Responden MK). Senada dengan itu, ada pendapat mengatakan bahwa "saya tidak membuat analisis kebutuhan kami langsung membuat program sesuai petunjuk dari kurikulum 2013" (Responden SB). Hal ini benar bahwa guru menjadikan SKL sebagai landasan perencanaan program namun tidak melakukan analisis kebutuhan untuk disesuaikan dengan lingkungan satuan pendidikan sebagaimana karakteristik K13.

Menurut Hamzah dan Mohamand (Uno \& Mohamad, 2017) pendidikan ialah peraduan antara kebutuhan belajar serta kegiatan mengajar wajib berjalan penuhi harapan. Harapan tersebut merupakan apa yang jadi kebutuhan siswa yang belajar sehingga terencana tujuan pendidikan yang diformulasikan oleh guru.

Berdasarkan penjelasan di atas, maka menurut peneliti dalam membuat program pembelajaran harus dilakukan analisis kebutuhan. Jadi standar kompetensi lulusan yang dijadikan sebagai acuan harus dianalisis dan dirancang sesuai dengan kebutuhan siswa di setiap satuan pendidikan tanpa menghilangkan kompetensi lulusan secara umum.

\section{Program Pembelajaran}

Sebagaimana diketahui bahwa dalam pengelolaan cara belajar ada beberapa susunan aktivitas yang butuh direncanakan terlebih dulu oleh guru. Aktivitas pemograman ini menuntut guru berasumsi logis, holistik serta analitis dalam memprediksi serta mengutip ketetapan mengenai unsur-unsur ataupun bagian terpaut dengan cara penataran yang hendak digunakan (Yamin et al., 2017).

\section{Input}

Evaluasi input berbicara tentang kegiatan kurikulum dan non kurikulum. Kegiatan kurikulum berupa penstrukturan program pembelajaran berupa topik-topik bahan ajar yang disiapkan dalam silabus dan RPP, sedangkan kegiatan non kurikulum atau ektrakurikuler berupa penstrukturan kegiatan tambahan diluar jam pelajaran. 
Fakta penelitian menggambarkan bahwa program pembelajaran baik kurikulum maupun ekstra kurikuler dari semester satu sampai dengan semester enam sudah terprogram dan terstruktur dengan baik sesuai dengan silabus, program semester dan program tahunan. Terlihat bahwa dalam program pembelajaran setiap semester sudah direncanakan dan setiap pokok bahasan atau materi pembelajaran terdistribusi dalam rencana pembelajaran di kelas.
Proses belajar melalui proses analitis serta objektif dan terencana merujuk pada kaidah-kaidah keilmuan positif di aspek pokok kependidikan. Sistem perancangan yang sempurna merupakan cara menyusun wajah proses belajar dengan memikirkan berbagai pandangan selaku prediktor berpengaruh supaya proses belajar aktif, inovatif, inovatif, efisien serta mengasyikkan untuk anggota yang dibimbing. Jika digambarkan seperti diagram berikut:

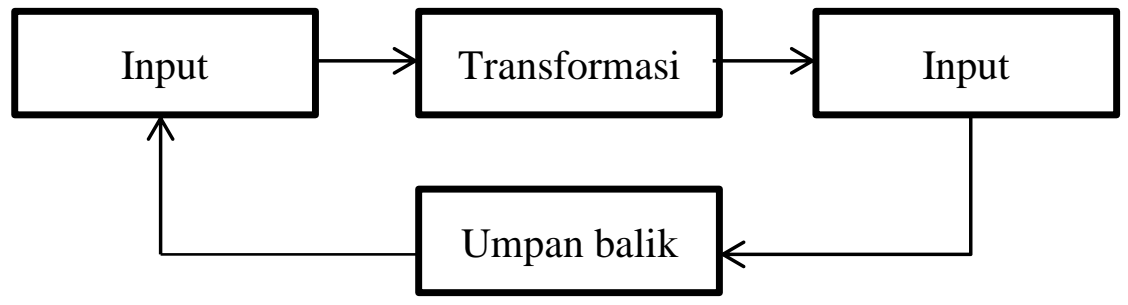

Gambar 1. Siklus input

Langkah-langkah penataran dalam RPP telah dijabarkan dengan cara pijat oleh guru kategori, diawali dari aktivitas dini, aktivitas inti, serta aktivitas akhir. Dalam perencanaan penataran tata cara yang dipakai guru telah bermacam- macam, Alat yang dipakai oleh guru pula telah bermacam- macam, misalnya: lukisan, kartu angka, denah, globe, serta wujud bangun informasi (Febrina et al., 2016).

Sesuai penjelasan di atas, maka terlihat jelas bahwa bahan ajar atau topik pembelajaran dalam silabus atau RPP disusun atau disiapkan dengan mempertimbangkan hal penting dalam proses belajar agar dapat mencerahkan dan memuaskan nara didik dalam proses belajar yang kontruktif. Hal strategis yang perlu dipertimbangkan adalah asas kebermanfaatan dan relevansi dengan kebutuhan peserta didik serta tuntutan lingkungan. Hal strategis lain yang juga perlu diperhatikan adalah strukur keilmuan 
dan proses aktualisasi keluasan materi pembelajaran yang mengacu kepada ketercapaian kompetensi dasar. Merancang

aktifitas belajar siswa menjadi penting agar siswa diberi keleluasaan dalam hal pengayaan materi.

Penentuan waktu jadi aspek pembatas untuk memikirkan daya serta besarnya materi didik dan kegiatan pembelajaran di kelas. Berdasarkan fakta bahwa topik pembelajaran yang telah disusun secara terstruktur terlihat ada beberapa materi pembelajaran yang terprogram dalam satu pertemuan, dua pertemuan bahkan tiga pertemuan. Hal ini dapat terjadi apabila guru melaksanakan analisis kurikulum dan kedalaman materi pada awal semester. Salmawati menemukan bahwa Kualifikasi Perencanaan Program Pembelajaran IPS di SDN Se-Wilayah IV Kecamatan Donri Donri Kabupaten Soppeng berada pada nilai kurang baik (Salmawati, 2017). Temuan tersebut dikaitkan dengan konsep perencanaan pembelajaran dalam Permendiknas Nomor 41 Tahun 2007 menjelaskan bahwa perencanaan program pembelajaran meliputi silabus dan rencana pelaksanaan pembelajaran (RPP) yang memuat identitas mata pelajaran, standar kompetensi, kompetensi dasar, indikator pencapaian kompetensi, tujuan pembelajaran, materi ajar, lokasi waktu, metode pembelajaran, kegiatan pembelajaran, penilaian hasil belajar, dan sumber belajar.

Perencanaan pembelajaran yang termuat dalam RPP menurut hemat peneliti, guru PAK wajib melakukan analisis kedalaman materi, asas relevansi terhadap kebutuhan siswa dan tuntutan lingkungan kemudian proses aktualisasi keilmuan untuk mencapai kompetensi dasar dengan mempertimbangkan ketersediaan waktu. Semua kegiatan ini wajib untuk dilakukan di awal semester.

\section{Proses}

Evaluasi terhadap proses pembelajaran merupakan point penting dalam evaluasi terhadap program pembelajaran, karena pada tahap proses seluruh perencanaan pembelajaran yang sudah terprogram dilaksanakan. Keberhasilan dari perencaan program pembelajaran dapat di ukur melalui proses pembelajaran oleh karena itu pada tahap proses ini peneliti mengevaluasi proses belajar yang terdiri dari kegiatan pendahuluan, inti dan penutup.

Tiap proses ataupun aktivitas pengajian guru senantiasa berdasar pada RPP yang telah disusunya, perihal ini buat melindungi supaya penataran jadi lebih terencana dan kesimpulan tujuan penataran yang sudah disusun bisa digapai dengan bagus (Anggraeni \& Akbar, 2018).

\section{Kegiatan pendahuluan}


Fakta penelitian tentang kegiatan pendahuluan menjelaskan bahwa guru melakukan orientasi dengan doa bersama, mengecek kehadiran siswa, kemudian merapikan posisi duduk. Guru menyatakan kembali bahan sebelumnya dan mengarahkan pada materi yang akan dipelajari dengan memberikan pertanyaan sekaligus memberikan motivasi serta memberitahukan faedah serta tujuan dari materi yang hendak dipelajari. Menurut Ridwan (Sani, 2016), aliran kognitivistik menganggap bahwa belajar adalah proses mental dalam mengelolah informasi dengan menggunakan strategi kognitif

Berdasarkan penjelasan di atas, maka dapat dianalisis bahwa guru agama Kristen di SMP Negeri 12 Kupang telah melaksanakan kegiatan pendahuluan pembelajaran dengan baik dan benar. Tanpa kegiatan pendahuluan yang baik dan benar, proses pelajaran tidak akan berjalan dengan baik yang berakibat pada ketercapaian tujuan pembelajaran. Fakta di lokasi penelitian menjelaskan bahwa guru mampu untuk mempersiapkan kondisi fisik maupun psikis peserta didik dengan memberikan apersepsi dan motivasi.

Menurut peneliti, siswa yang berada dalam kondisi siap belajar baik fisik maupun psikis akan sangat mempengaruhi hasil belajar. Kesiapan fisik meliputi tubuh sehat, jauh dari gangguan mengantuk, keadaan tubuh tidak lesuh. Kesiapan psikis ditandai dengan adanya gairah untuk membiasakan berkonsentrasi, sanggup berkonsentrasi dan adanya kesadaran dalam belajar. Siswa yang berada pada keaadaan siap belajar membuatnya siap untuk memberi jawaban atau respon dalam mencapai tujuan belajar.

Kegiatan inti

Evaluasi kegiatan inti pembelajaran dalam penelitian ini peneliti fokuskan pada pelaksanaan program pembelajaran di SMP Negeri 12 Kupang terkait dengan modelmodel pembelajaran yang terencana dalam program pelaksanaan pembelajaran. Pelaksanaan pembelajaran merupakan implementasi dari rencana pembelajaran yang telah dirancangkan oleh guru. mekanisme pembelajaran yang harus disiapkan guru sebelum melakukan pembelajaran maka sekurang-kurangnya perlu untuk menyusun berupa silabus dan RPP. Kenyataannya bahwa silabus dan RPP sudah dirancangkan oleh guru sesuai dengan tema pembelajaran.

Model proses belajar ialah semua rantaian penyajian modul kepada nara didik yang mencakup seluruh pandangan dan sarana yang dipakai dengan cara langsung. Peranan dari bentuk proses belajar merupakan bagaikan prinsip untuk guru dalam melakukan proses belajar. Perihal ini membuktikan kalau tiap bentuk yang hendak dipakai dalam pembelajaran memastikan fitur yang hendak digunakan dalam proses 
belajar. Tidak hanya itu bentuk pembelajaran berperan seperti prinsip untuk para perencana pembelajaran dalam merancang serta melakukan kegiatan berlatih membimbing alhasil tujuan penataran berhasil. Model pembelajaran yang mendukung keterlaksanaan kurikulum 2013 yakni model pembelajaran penemuan (Discovery learning), model pembelajaran berbasis masalah (problem based learning), pembelajaran berbasis projek (project based learning), model pembelajaran konteksual (contextual learning) dan pembelajaran kooperatif (cooperative learning).

Berdasarkan hasil penelitian model pembelajaran yang digunakan dalam mendukung keterlaksanaan program pembelajaran PAK di SMP N 12 Kupang meliputi model pembelajaran penemuan (Discovery learning), pembelajaran berbasis masalah (problem based learning), pembelajaran berbasis projek (Cooperative learning) dan model sendiri.

Fakta penelitian menunjukkan bahwa model pembelajaran PBL diprogramkan dan dilaksanakan oleh guru PAK di SMP N 12 Kupang namun belum maksimal karena guru kurang memahami langkah-langkah yang benar dari model ini. Guru kurang peka dan kreatif untuk menghadirkan masalahmasalah faktual yang dapat dijadikan sebagai bahan ajar bagi siswa. Kemudian siswa yang kurang aktif dalam pembelajaran juga turut mempengaruhi guru dalam menerakan model pembelajaran ini. Faktor lain juga yaitu guru tidak menggunakan RPP sebagai panduan di dalam kelas, guru lebih mengandalkan buku teks guru. Faktor penyebab lain belum maksimalnya penerapan model PBL karena respon siswa yang pasif.

Siswa yang pasif dalam pembelajaran sangat mempengaruhi guru untuk menerapkan model pembelajaran. Keadaan ini menuntut guru untuk kreatif melihat situasi kelas kemudian mengkondisikannya serta mengarahkannya pada model pembelajaran yang ada. Benar bahwa siswa tidak semuanya memiliki kemampuan untuk belajar menggunakan model PBL, hal ini terlihat pada tahap analisis dan evaluasi pemecahan masalah.

Berdasarkan penjelasan dan analisis di atas, maka model pembelajaran ini belum maksimal diterapkan baik dari sisi guru maupun siswa. Guru perlu untuk meningkatkan kemampuan menganalisis penempatan model pembelajaran, kepekaan terhadap situasi dan kondisi kelas, serta guru harus kreatif dalam membimbing siswa untuk belajar dalam situasi apapun.

Cooperative learning

Cooperative learning menekankan kegiatan anak didik bersama-sama secara berkelompok dan tidak tersendiri. Siswa dengan pembelajaran kooperatif dan 
kompetitif gaya memiliki skor lebih tinggi dalam pendekatan pembelajaran daripada siswa dengan gaya belajar menghindar, bergantung, dan partisipatif (Çolak, 2015).

Pada hakikatnya pembelajaram model kooperatif sama dengan kerja kelompok. Oleh karena itu banyak guru yang mengatakan tidak ada sesuatu yang aneh dalam cooperatif learning, karena mereka berangapan bahwa telah biasa melakukan pembelajaran dalam bentuk kelompok.

Guru tidak hanya memainkan peran kunci dalam penataan kelompok sehingga menjadi komponen kunci. Kemungkinan untuk memfasilitasi kerjasama yang sukses terbukti tetapi mereka juga memiliki peran dalam mempromosikan interaksi antar siswa (Gillies, 2016). Artinya bahwa dalam pembelajaran ini hendak terwujud sesuatu interaksi yang lebih besar, ialah interaksi serta komunikasi yang dilakukan antara guru serta anak didik, anak didik dengan anak didik serta anak didik dengan guru (multiway traffic comunication).

Salah satu penelitian terdalulu memberikan hasil penelitian yang kreatif dan berbeda Hartanty (Nur Fidiyanti, 2017) menunjukkan bahwa: pertama, motivasi belajar siswa sebelum dan sesudah penerapan model pembelajaran kooperatif meningkat namun masih termasuk kategori rendah. Kedua, motivasi belajar siswa sebelum dan sesudah penerapan metode konvensional tidak meningkat. Ketiga, motivasi belajar secara simultan antara siswa yang belajar. Namun fakta di lokasi penelitian menunjukkan hal yang berbeda ketika observasi dilakukan.

Pembelajaran berkelompok benar dilakukan namun belum dapat dikatakan sebagai model kooperatif learning, karena yang terjadi adalah komunikasinya belum multi way traffic. Komunikasi yang terlihat masih berada pada level guru menjelaskan cara menyelesaikan kerja kelompok kemudian komunikasi antar siswa namun sebaliknya komunikasi siswa terhadap guru belum ada. Berdasarkan penjelasaan di atas dapat dianalisis bahwa benar memang adanya kegiatan belajar kelompok, namun belum sampai pada tingkat kooperatif karena arah komunikasi belum multy-way traffic.

Fakta yang terjadi di lokasi penelitian langkah pembelajaran kooperatif yang kurang maksimal dilaksanakan adalah kurangnya penjelaskan tentang tujuan suatu topik diskusi dalam kelompok. Selain itu kurangnya pemberian motivasi pada siswa sehingga siswa semangat dalam melaksanakan belajar secara bersama atau kelompok. Dengan kurangya penjelasan tujuan, pemberian motivasi membawa dampak yang kurang baik bagi keaktifan belajar siswa. Hal ini terlihat pada fakta di atas bahwa arah komunikasi dalam 
pembelajaran kooperatif belum terbangun dengan baik.

Menurut peneliti model pembelajaran kooperatif jika diterapkan dengan baik maka akan sangat sesuai dengan level kemampuan siswa SMP Negeri 12 Kupang. Oleh karena itu guru perlu untuk melaksanakan evaluasi terhadap penerapan model pembelajaran sehingga mampu menempatkan model pembelajaran sesuai kemampuan dan kebutuhan siswa. Gurupun dengan adanya evaluasi dapat memperbaiki penerapan langkah-langkah model pembelajaran.

Berdasarkan pemaparan di atas, maka kegiatan inti proses belajar belum berjalan dengan baik sesuai dengam model-model pembelajaran yang direncanakan dalam program pembelajaran. Belum maksimalnya pelaksanaan kegiatan inti pembelajaran secara keseluruhan disebabkan oleh berbagai faktor. Selain faktor yang telah diuraikan disetiap item di atas berdasarkan analisa peneliti, terdapat faktor lain yang menjadi kendala kurang maksimalnya pelaksanaan kegiatan inti. Hasil wawancara terkait faktor lain yang menjadi kendala: "pada saat mengajar, anak-anak kurang perhatian karena fasilitas sekolah yang terbatas serta buku siswa yang kurang" (Responden MK). Sebenarnya lewat teknologi informasi bisa tetapi karena keterbatasan kami maka seperti itu saja kami mengajar apa adanya (Responden SB).
Sesuai fakta ini, maka dapat di analisis bahwa faktor lain yang menjadi kendalam dalam kegiatan inti adalah keaktifan siswa dan kemampuan guru dalam penggunaan teknologi informasi yang belum memadai. Keaktifan siswa dalam pembelajaran ditentukan oleh kegiatan pendahuluan pembelajaran. Karena di dalam kegiatan pemdahuluan terdapat apersepsi dan motivasi untuk membangkitkan semangat siswa dalam belajar. Sedangkan kemampuan guru dalam hal penggunaan teknologi informasi ditentukan oleh pengembangan kompetensi profesionalisme guru.

\section{Kegiatan Penutup}

Sesuai dengan fakta penelitian kegiatan penutup pembelajaran menunjukan bahwa kegiatan pembelajaran dilaksanakan dengan baik namun belum maksimal. Terlihat guru sudah melakukan kesimpulan atau rangkuman serta memberikan tugas terkait materi yang telah dipelajari sampai pada doa penutup namun masih terdapat kekurangan dimana guru tidak melakukan penilaian terhadap pekerjaan siswa secara individu maupun kelompok. Mulyasa (Mulyasa, 2017) menjelaskan bahwa aktivitas akhir belajar ataupun penutup bisa diberikan kegiatan yang harus dikerjakan dan post tes. Tugas yang diberikan merupakan tindak lanjut dari pembelajaran inti atau pembentukan kompetensi yang berkenaan dengan materi 
standar yang telah dipelajari maupun materi yang akan dipelajari berikutnya.

Kenyataan yang peneliti temui bahwa pada akhir proses belajar guru menyerahkan tugas berupa post test yang akan mereview kembali tentang kegiatan inti pembelajaran. Guru memberikan tugas secara mandiri dan kelompok. Selain itu juga guru memberikan tugas projek dan produk seperti penjelasan Syaffrudin (Nurdin, 2018) bahwa projek merupakan kewajiban yang diserahkan oleh pada nara didik dalam rangkaian proses terteentu, sebaliknya produk merupakan evaluasi yang memohon nara didik menciptakan sesuatu hasil.

Berdasarkan uraian di atas, menurut peneliti hal yang penting dalam kegiatan penutup pembelajaran bukan hanya terletak pada pemberian tugas atau projek. Hal penting lain yang harus dilakukan adalah menyimpulkan hasil pembelajaran, melakukan penguatan, dan mengevaluasi capaian pembelajaran dengan melibatkan siswa. Hal ini harus dilakukan agar siswa secara langsung dapat menarik makna dari proses pembelajaran yang telah dilakukannya.

\section{Produk}

Suguhan penilaian produk pada hasil riset ini mencakup perolehan hasil berlatih nara didik yang dibimbing. Capaian hasil belajar yang dimaksud adalah capaian hasil belajar dalam ranah afektif, kognitif dan psikomotor. Fakta penelitian menunjukkan bahwa pada Kelas VII, VIII dan IX ketuntasan belajar yang sama pada tiga ranah. Untuk ranah afektif terlihat bahwa hasil yang dicapai masuk dalam kategori cukup, kemudian pada ranah kognitif menunjukkan hasil pada kategori cukup dan pada ranah psikomotor menunjukkan hasil yang berbeda dari kedua ranah yang lain yakni capaian yang diraih berada dalam kategori baik.

Bersumber pada filosofi melatih diri sempurna, seseorang nara didik dilihat berhasil berlatih bila sanggup menuntaskan, memahami kompetensi, serta kepribadian ataupun menggapai tujuan proses belajar minimun $65 \%$ dari semua tujuan belajar, sebaliknya kesuksesan kategori diamati dari jumlah nara didik yang sanggup menuntaskan ataupun menggapai minimun $65 \%$, sedikitnya $85 \%$ dari jumlah nara didik yang ada di kategori itu (Mulyasa, 2017).

Sesuai dengan fakta penelitian di atas, ranah afektif dan kogitif berada dalam kategori cukup. Fakta ini menunjukkan bahwa kedua ranah ini jika dilihat dari teori ketuntasan berada di bawah standar minimal. Selanjutnya pada ranah psikomotor menunjukan hasil yang baik jadi berdasarkan teori ketuntasan ranah ini melebihi standar minimal. Berdasarkan capaian belajar siswa di SMP Negeri 12 Kupang, maka dapat dikatakan bahwa hasil pembelajaran belum 
mencapai standar ketuntasan minimal.

Berdasarkan uraian di atas, dapat dianalisis bahwa hasil yang kurang maksimal ini terjadi karena proses pembelajaran belum berjalan dengan baik, sarana-prasarana belum mendukung, waktu pembelajaran yang tidak efektif, kompetensi profesional guru yang perlu ditingkatkan.

\section{SIMPULAN DAN SARAN}

Setelah melakukan evaluasi program pembelajaran PAK di SMP Negeri 12 Kupang menggunakan model CIPP maka ditinjau dari segi konteks masuk dalam kategori Baik. Lebih dalam diperhatikan item tujuan yang mencakup standar kompetensi lulusan dan pembuatan analisis kebutuhan pada program pembelajaran Pendidikan Agama Kristen. Dalam merancangkan program, terdapat Standar Kompetensi Lulusan sebagai acuan namun tidak terdapat analisis kebutuhan dalam perancanaan program.

Pelaksanaan program pembelajaran ditinjau dari segi input masuk dalam kategori baik. Program pembelajaran dirancang dan terstruktur dengan baik sesuai dengan pembagian kesempatan yang menjadi faktor penentu dalam proses pembelajaran serta kedalam materi pelajaran. Hal ini termuat dalam RPP dengan melihat asas kebermanfaatan dan relevansi dengan kebutuhan siswa di sekolah.
Pelaksanaan program pembelajaran ditinjau dari segi proses masuk dalam kategori kurang efektif. Proses pembelajaran mencakup pendahuluan, isi dan penutup. Item pendahuluan dikerjakan guru dengan cakap sesuai dengan rancangan yang terdapat didalam RPP.

Saran perbaikan kedepan yakni pertama, konteks. Guru perlu membuat analisis kebutuhan secara terstruktur dalam program pembelajaran. Kedua, Input. Guru perlu membuat analisis kedalaman materi dalam penstrukturan program pembelajaran yang termuat di dalam RPP. Ketiga, process. Pihak sekolah Perlu mengadakan workshop berbagai model pembelajaran melalui kerjasama dengan pengawas dan pemerintah untuk mendampingi pelatihan untuk guru di sekolah. Keempat, produk. Guru perlu membuat administrasi penilaian dengan baik dan sesuai dengan regulasi yang ditetapkan.

\section{DAFTAR REFERENSI}

Anggraeni, P., \& Akbar, A. (2018). Kesesuaian Rencana Pelaksanaan Pembelajaran dan Proses Pembelajaran. Universitas Syiah Kuala, 6(2), 55-65. http://www.jurnal.unsyiah.ac.id/PEAR/artic le/view/12197

Aziz, S., Mahmood, M., \& Rehman, Z. (2018). Implementation of CIPP Model for Quality Evaluation at School Level: A Case Study. Journal of Education and Educational Development, 5(1), 189-206. https://doi.org/10.22555/joeed.v5i1.1553

Bhakti, Y. B. (2017). Evaluasi Program Model CIPP pada Proses Pembelajaran IPA. JIPFRI (Jurnal Inovasi Pendidikan Fisika Dan Riset 
IImiah), 1(2), 75-82. https://doi.org/10.30599/jipfri.v1i2.109

Çolak, E. (2015). The Effect of Cooperative Learning on the Learning Approaches of Students with Different Learning Styles. Eurasian Journal of Educational Research, 59, 17-34. https://eric.ed.gov/?id=EJ1070614

Darmawan, I. P. A., \& Sujoko, E. (2013). Revisi taksonomi Pembelajaran Benyamin S. Bloom. Satya Widya, 29(1), 30-39. https://doi.org/10.24246/j.sw.2013.v29.i1. p30-39

Eryanto, H., Marsofiyati, \& Swaramarinda, D. (2016). Evaluasi Program Ujian Nasional (UN) Pada SMK Negeri Di Jakarta Selatan. Econosains Jurnal Online Ekonomi Dan Pendidikan, 14, 26-41. https://doi.org/10.21009/econosains.0142. 03

Febrina, F., Hajidin, \& Mahmud. (2016). Kompetensi Guru dalam Perencanaan Pembelajaran di SDN 2 Banda Aceh. Jurnal IImiah Mahasiswa Prodi PGSD FKIP Unsyiah, 1(1), 40-50.

Gillies, R. M. (2016). Cooperative Learning: Re e Learning: Review of Resear view of Research and $\mathrm{Pr}$ ch and Practice. Australian Journal of Teacher Education, 41(3),

41. https://doi.org/10.14221/ajte.2016v41n3.3

Junanto, S., \& Kusna, N. A. A. (2018). Evaluasi Program Pembelajaran di PAUD Inklusi dengan Model Context, Input, Process, and Product (CIPP). INKLUSI, 5(2), 179-194. https://doi.org/10.14421/ijds.050202

Mahmudi, I. (2011). CIPP: Suatu Model Evaluasi Program Pendidikan. In At-Ta'dib (Vol. 6, Issue 1). https://doi.org/10.21111/ATTADIB.V6I1.551

Mawarsari, V. D., \& Prihaswati, M. (2014). Evaluasi Pembelajaran Matematika Menggunakan Model CIPP Pada Kejar Paket B Kota Semarang. PROSIDING SEMINAR NASIONAL \& INTERNASIONAL, 0. http://103.97.100.145/index.php/psn1201 2010/article/view/1211

Mirwati, Ali, S., \& Saludung, J. (2015). Evaluasi Program Pembelajaran Kimia Pada SMA Negeri 3 Watan Soppeng. Jurnal Penelitian Dan Evaluasi Pendidikan, 1(1), 1-9. https://ojs.unm.ac.id/

Mulyasa, E. (2017). Pengembangan dan
Implementasi Kurikulum 2013. Remaja Rosdakarya.

Muyasaroh, \& Sutrisno, S. (2014). Pengembangan Instrumen Evaluasi CIPP Pada Program Pembelajaran Tahfiz Al-Qur'an Di Pondok Pesantren. Jurnal Penelitian Dan Evaluasi Pendidikan, 18(2), 215-233. https://doi.org/10.21831/pep.v18i2.2862

Nur Fidiyanti, H. H. (2017). Effect Of Implementation Of Cooperative Learning Model Make A Match Technique On Student Learning Motivation In Social Science Learning. International Journal Pedagogy of Social Studies, 2(1), 104. https://doi.org/10.17509/ijposs.v2i1.8667

Nurdin, S. (2018). Pengembangan Kurikulum dan Rencana Pembelajaran Semester (RPS) Berbasis KKNI di Perguruan Tinggi. Jurnal Pendidikan Islam-Murabby, 1(2), 140-147. http://ejournal.uinib.ac.id/index.php?journ al=MRB

Rudy, C. (2015). The perspective of curriculum in Indonesia on environmental education. International Journal of Research Studies in Education, 4, 77-83. https://doi.org/10.5861/ijrse.2014.915

Salmawati. (2017). Evaluasi Program Pembelajaran IPS di SDN Se-Wilayah IV Kecamatan Donri Donri, Kabupaten Soppeng. PEP Educational Assessment, 1(1), 75-84. http://ojs.unm.ac.id/index.php/UEA

Sani, R. A. (2016). Inovasi Pembelajaran. Bumi Aksara.

Uno, H. B., \& Mohamad, N. (2017). Belajar dengan Pendekatan PAILKEM. Bumi Aksara.

Widoyoko, S. E. P. (2013). Evaluasi program pembelajaran: panduan praktis bagi pendidik dan calon pendidik. Pustaka Pelajar.

Winarni, L., Judistianti, T., Ruslami, R., Husin, F., Sutedja, E., Herawati, D., \& Idrajinata, P. (2017). Penggunaan Model CIPP dalam Evaluasi Kurikulum Inti Pendidikan D-III Kebidanan. Jurnal Pendidikan Dan Pelayanan Kebidanan Indonesia, 1, 8. https://doi.org/10.24198/ijemc.v1i1.77

Yamin, M., Aswirna, P., Fahmi, R., \& Nurdin, S. (2017). Material Effect on Entrepreneurship Learning towards Interest in Entrepreneurship Activities of Students 7(2). Journal of Research in Marketing, 7(2), 544-550. 